\title{
A Tér és Társadalom 2012-ben
}

\author{
Space and Society in 2012
}

\section{CZIRFUSZ MÁRTON, TAGAI GERGELY}

A Tér és Társadalom folyóiratban a tavalyi 1. számban hagyományteremtő módon összeállítást jelentettünk meg a folyóirat 2011-es szerzőiről és lektorairól. Ebben az írásban hasonló tematikában összegezzük a 2012-es évet.

\section{A folyóirat szerzői 2012-ben}

A Tér és Társadalom 2012-es szerzőinek területi megoszlását a Szerzőink rovatban megjelent munkahely településével azonosítottuk. A szakterületek azonosításában az MTA köztestületi tagjainál a tudományos bizottságot vettük figyelembe, a többieket egyéb források (önmeghatározásuk, munkahelyi honlapok stb.) alapján soroltuk be az egyes csoportokba.

A folyóirat szerzői között mindenkit szerepeltettünk, aki tavaly egyedüli vagy társszerzőként a Tér és Társadalom bármely rovatába írt. Ha valaki több cikk megírásában müködött közre, akkor is csak egyszer vettük számításba.

2012-ben 72 szerzőnk intézményi kötődését tekintve a korábbiakhoz képest (ahol 2011-ben például a felsőoktatási szféra dominált) kiegyenlítettebb volt a felsőoktatási intézmények és kutatóintézetek aránya. 33 területi kutatásokkal foglalkozó kolléga valamely hazai vagy külföldi egyetemet/föiskolát jelölte meg munkahelyéül, míg kutatóintézetekhez 30 szerző munkája kötődik. Közülük legtöbben közeli munkatársaink, az MTA KRTK Regionális Kutatások Intézetének (RKI) alkalmazottai. Ugyanakkor más MTA intézetekből és egyéb kutatóhelyekről is érkeztek szerzőink a 2012-es évben. Több TéT-es szerző dolgozik az állami szférában, közigazgatási vagy más állami intézményekben. Azon szerzők között, akik intézményi hovatartozásukat nem adták meg, több nyugdíjas, de jelenleg is aktív szakember van.

A Tér és Társadalom szerzőinek területi megoszlása (1. ábra) a tavalyihoz hasonló képet mutat, de természetesen ezt nagyban befolyásolja az, hogy az előzőekben említett felsőoktatási és közigazgatási intézmények, valamint kutatóintézetek egy meghatározott települési körhöz tartoznak. A szerzők relatív

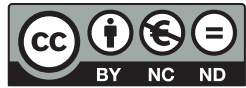


1. ábra: A Tér és Társadalom szerzőinek (munkahely szerinti) területi megoszlása, 2012 Spatial distribution of Space and Society's authors (according to workplace), 2012

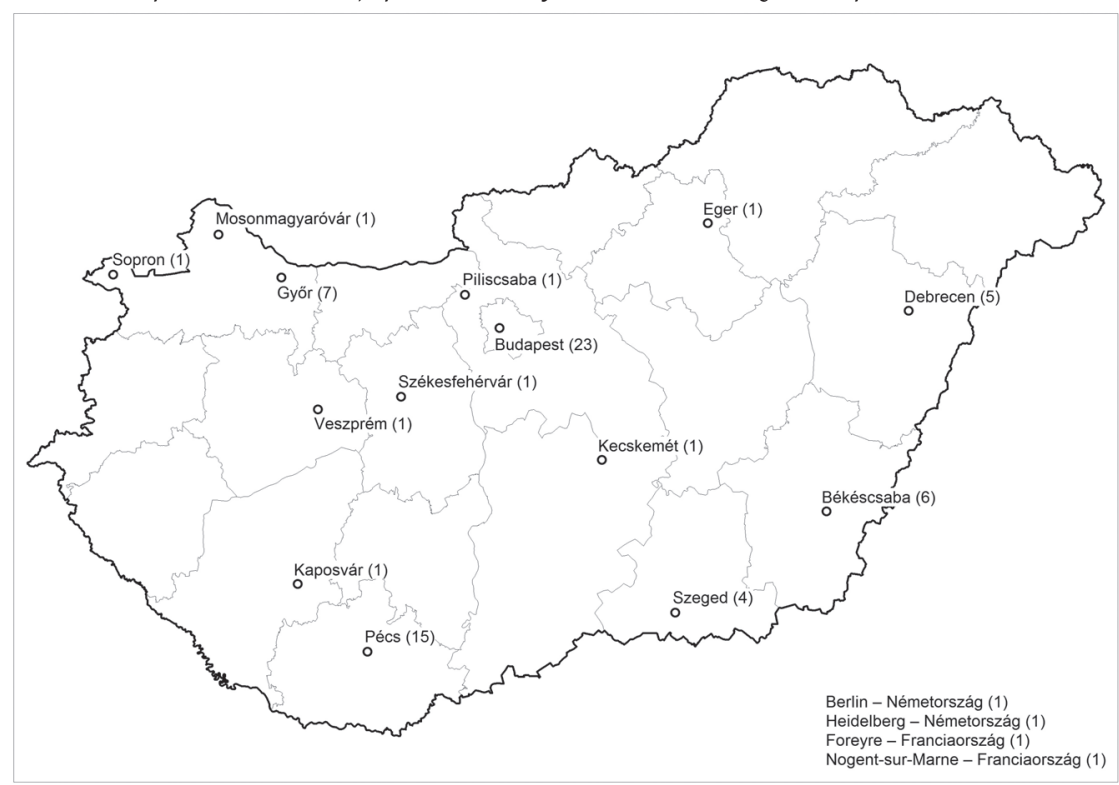

többsége 2012-ben is budapesti volt, 23-an jelöltek meg fővárosi intézményt munkahelyükként. A vidéki felsőoktatási és kutatóintézeti központok közül a legtöbb szerzőt (15-öt) Pécs városa adta, de több tanulmány érkezett Debrecenből, Szegedről, valamint Győrből és Békéscsabáról is, nem utolsó sorban RKI-s kollégák tollából. A további vidéki felsőoktatási intézményeket (pl. Sopron, Veszprém, Piliscsaba, Eger) egy-egy szerző képviselte. A TéT által felvállalni kívánt nemzetközi nyitás csak kismértékben mondható sikeresnek. 2012-ben külföldről mindössze két francia és két német illetőségű szerző szerepelt - közülük egy volt külföldön dolgozó magyar szakember.

Ezzel szemben úgy érezzük, hogy a szakmák közötti nyitás kifejezetten sikeres volt, 2012-ben ismét számos szakterületről érkező szerzőt sikerült megszólítani. Az intézményi hovatartozás, valamint az MTA köztestületekben deklarált szakterület alapján a legtöbben (22-22-en) a földrajztudomány (társadalomföldrajz) és a regionális tudomány területéről kerültek ki. A regionalisták így az előző évnél nagyobb számban jelentek meg a hazai regionális tudomány meghatározó folyóiratában, nem utolsó sorban annak köszönhetően, hogy RKI-s kollégák is nagyobb számban publikáltak a lapban a korábbiakhoz képest. A rokontudományok közül a szociológia és a közgazdaság-tudomány (agrár-közgazdaságtan is) szakterületről sikerült még nagyobb számban szerzőket megszólítanunk, de több szerzőt üdvözölhettünk a környezettudomány, közlekedéstudomány, történettudomány és turizmustudomány berkeiből is. 2012-ben az állam- és jogtudományt, a szociálpolitikát és az urbanisztikát is képviselte egy-egy szerző. 
2012-ben szerzőink voltak:

\begin{tabular}{lll} 
Albagli, Claude & Honvári János & Nagy Gábor \\
Bajmócy Zoltán & Hopkó Iván & Nemes Nagy József \\
Baros Zoltán & Horváth Gyula & Orosz Éva \\
Barta Györgyi & Jelinek Csaba & Pénzes János \\
Bassa László & Keserű Imre & Rácz Szilárd \\
Beluszky Pál & Kóbor Krisztina & Ragadics Tamás \\
Bodor Norbert & Kovács Éva & Rechnitzer János \\
Bögre Zsuzsanna & Kovács Sándor Zsolt & Reisinger Adrienn \\
Brenner János & Kovács Szilvia & Rey, Violette \\
Czirfusz Márton & Kovács Zoltán & Sarudi Csaba \\
Csaba László & Kugler József & Sebestyén Tamás \\
Csatári Bálint & Kundi Viktória & SulyokJudit \\
Dombi Mihály & Lados Mihály & Szilágyi Zsolt \\
Duray Balázs & Lengyel Imre & Sziva Ivett \\
Dusek Tamás & Leveleki Magdolna & Tagai Gergely \\
Egyed Ildikó & Ludescher Gabriella & Tamáska Máté \\
Erdői Ferenc & Lux Gábor & Tánczos Lászlóné \\
Faragó László & Meusburger, Peter & Timár Judit \\
Fekete Attila & Mezei Cecília & Tóth Balázs István \\
Földi Zsuzsa & Mezei Katalin & Vadál Ildikó \\
Gál Zoltán & Molnár András & Váradi Zsuzsanna \\
Gyapay Borbála & Molnár Ernő & Varga Ágnes \\
Hajdú Zoltán & Móricz Ádám & Velkey Gábor \\
Hardi Tamás & Nagy Erika & Vidra Zsuzsanna \\
& & \\
\hline & &
\end{tabular}

\section{A folyóirat lektorai 2012-ben}

A Tér és Társadalom lektorai 2012-ben is óriási segítséget nyújtottak ahhoz, hogy a folyóirat magas színvonalát fenntarthassuk. A szerkesztőség munkájának támogatásában, a szerzők tanulmányainak tartalmi javításában nagy szerepük volt a számos szakterületet képviselő lektoroknak.

A lektori munkák során a legnagyobb arányban ismét felsőoktatási intézményekben és kutatóintézetekben dolgozó, szakterületükön nevet szerzett, többnyire tudományos fokozattal rendelkező munkatársak közreműködésére számítottunk. A 2012-es év 74 lektorának döntő többsége - 32 kutatóintézeti és 30 felsőoktatásban alkalmazott kolléga - kötődött ezekhez az intézményekhez. Az előző évhez képest nagyobb mértékben számítottunk a Regionális Kutatások Intézetének munkatársaira. Közülük 24 lektor került ki, azaz majdnem minden második kutató kollégánk munkájára számíthattunk ezen a téren. A többi kutatóintézeti lektor közül a legtöbben az MTA CsFK Földrajztudományi Intézetében 
dolgoznak, de sikerült a lektorálási munkán keresztül megszólítanunk anyaintézményünk, az MTA Közgazdaság- és Regionális Tudományi Kutatóközpont más intézetébe tartozó munkatársainkat is. Több minisztériumban, illetve az államigazgatás egyéb területén dolgozó lektort is felkértünk, akik szakterületüknek megfelelően segítették a Tér és Társadalom szerkesztésének ezen fázisát. Emellett múzeumok, levéltárak alkalmazottai és a nonprofit szféra képviselői is közreműködtek a lektorálási folyamatban.

A Tér és Társadalom lektorainak területi megoszlása (2. ábra) döntően nem változott 2011-hez képest. Budapest túlsúlyát (33 fö, a lektorok 45\%-a) nem sikerült mérsékelni, ez a szerzők megoszlásánál erőteljesebben érvényesült 2012ben is. 2011-ben a fơváros mellett Győr, Pécs és Szeged emelkedett ki, 2012-ben 12 lektor munkahelye volt Pécsett (többségükben intézeti kollégáink); Győrből 6, Békéscsabáról 3 fó segítette a szerkesztési folyamatot bírálatával. A felsőoktatási (és RKI-s) központok előbbi településeken kívül általában 1-3 lektort adtak a folyóirat számára. Tavaly 2 külföldön élő szakembert kértünk fel lektori vélemény írására, ez az érték a magyar nyelvismeret hiányában nem valószínű, hogy emelkedni fog a jövőben.

2011-hez hasonlóan az írások körültekintő olvasószerkesztését Marosi Lajos végezte. Nyugdíjba vonulása miatt a 2012/4. szám volt az utolsó, amely az ő keze nyomát viselte; a Tér és Társadalomnál végzett kétéves munkáját ezúton is nagyon köszönjük! Az angol nyelvű absztraktok nyelvi (és esetenként tartalmi) javításáért ismét Thomas Richersnek tartozunk köszönettel.

1. ábra: A Tér és Társadalom lektorainak (munkahely szerinti) területi megoszlása, 2012 Spatial distribution of Space and Society's reviewers (according to workplace), 2012

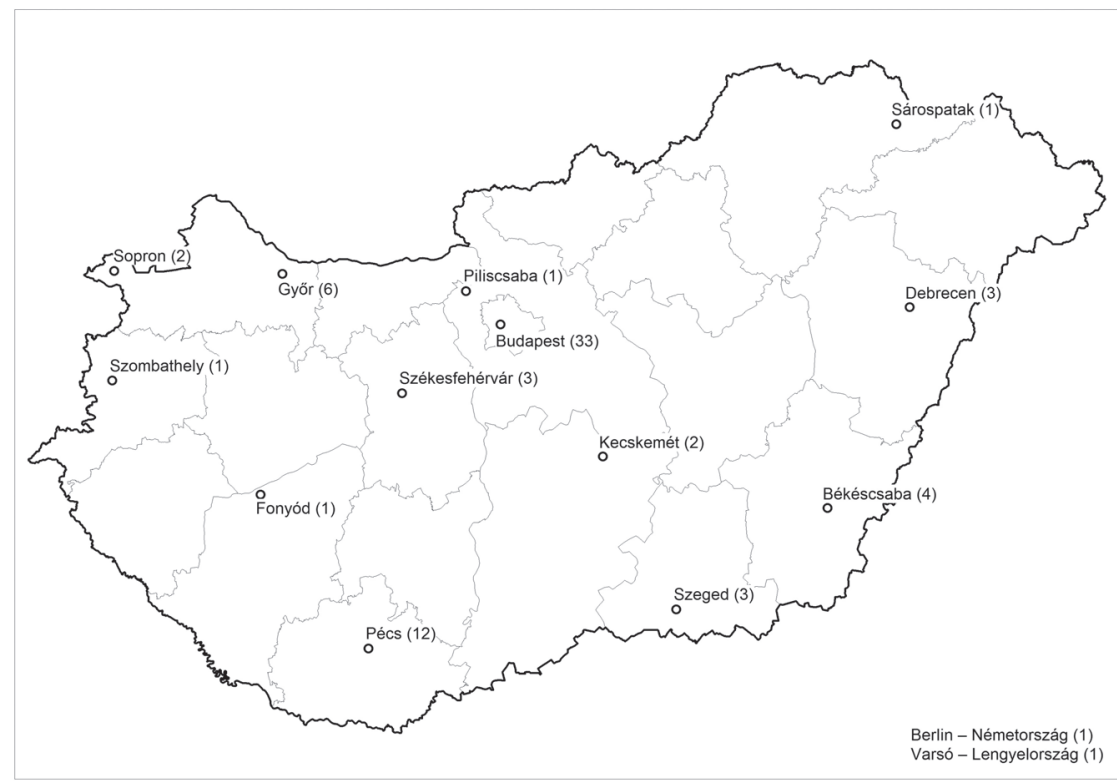


A Tér és Társadalom számára lektori tevékenységet végző (2012 januárja és 2013 januárja között bírálatát elküldő) személyekről teljes lista összeállítására törekedtünk. Amennyiben saját hibánkból valakit kihagytunk, kérjük, jelezze a szerkesztőség számára, hogy kiegészíthessük a névsort.

2012-ben lektoraink voltak:

$\begin{array}{lll}\text { A. Gergely András } & \text { Imre Gabriella } & \text { Pálné Kovács Ilona } \\ \text { Baranyai Nóra } & \text { Izsák Éva } & \text { Perger Éva } \\ \text { Baross Pál } & \text { Jakobi Ákos } & \text { Rátz Tamara } \\ \text { Barta Györgyi } & \text { Jankó Ferenc } & \text { Rechnitzer János } \\ \text { Beluszky Pál } & \text { Juhász Krisztina } & \text { Rédei Mária } \\ \text { Bernek Ágnes } & \text { Karácsonyi Dávid } & \text { Reisinger Adrienn } \\ \text { Brenner János } & \text { Kiss János Péter } & \text { Sipos András } \\ \text { Czira Tamás } & \text { Korompai Attila } & \text { Smahó Melinda } \\ \text { Czirfusz Márton } & \text { Kovács Dezső } & \text { Sütő Attila } \\ \text { Csatári Bálint } & \text { Kovács Teréz } & \text { Szerb László } \\ \text { Csizmadia Zoltán } & \text { Kovács Zoltán } & \text { Szirmai Viktória } \\ \text { Dusek Tamás } & \text { Kozma Gábor } & \text { Szokolay Örs } \\ \text { Egedy Tamás } & \text { Kuti Mónika } & \text { Tagai Gergely } \\ \text { Ekéné Zamárdi Ilona } & \text { Lengyel Balázs } & \text { Tamás Edit } \\ \text { Faragó László } & \text { Lux Gábor } & \text { Timár Judit } \\ \text { Földi Zsuzsa } & \text { Madarász Aladár } & \text { Tóth Balázs István } \\ \text { Gál Zoltán } & \text { Mészáros Rezső } & \text { Uzzoli Annamária } \\ \text { Gödri Irén } & \text { Michalkó Gábor } & \text { Váradi Monika } \\ \text { Győri Róbert } & \text { Nagy Erika } & \text { Varga Attila } \\ \text { Gyuris Ferenc } & \text { Nagy Gábor } & \text { Varjú Viktor } \\ \text { Hajdú Zoltán } & \text { Nagy Terézia } & \text { Velkey Gábor } \\ \text { Hinek Mátyás } & \text { Németh Nándor } & \text { Vigvári András } \\ \text { Horváth Gyula } & \text { Nikodémus Antal } & \text { Virág Tünde } \\ \text { Horváth M. Tamás } & \text { Osváth László } & \text { Wisniewski Anna }\end{array}$

